\title{
Research on the Ownership Structure and Market Value of Chinese Listed Commercial Banks
}

\author{
Yao Ni \\ Business School, Nanjing Normal University, Jiangsu Province, China \\ Email: cloris_nau@163.com
}

How to cite this paper: Ni, Y. (2019) Research on the Ownership Structure and Market Value of Chinese Listed Commercial Banks. American Journal of Industrial and Business Management, 9, 1995-2007. https://doi.org/10.4236/ajibm.2019.911131

Received: October 8, 2019

Accepted: November 19, 2019

Published: November 22, 2019

Copyright (อ 2019 by author(s) and Scientific Research Publishing Inc. This work is licensed under the Creative Commons Attribution International License (CC BY 4.0).

http://creativecommons.org/licenses/by/4.0/

\section{c) (i) Open Access}

\begin{abstract}
In recent years, the external Sino-US trade war has become increasingly fierce. Domestic Internet Finance has a strong impact on Chinese traditional Banking Industry, which has severely squeezed the business growth model of commercial banks with interest rate differentials, making the domestic financial industry increasingly competitive. The environment at home and abroad is becoming more and more complex, and the Chinese banking industry is facing a severe transformation crisis and challenge. This paper analyzes the market value of China's listed commercial banks by arranging the data of China's listed commercial banks, using descriptive analysis, correlation analysis and regression analysis, then studies the relationship between ownership structure and market value of listed commercial banks in China from three aspects: ownership concentration check-and-balance of ownership and separation of ownership and control. It is concluded that the shareholding ratio of state-owned shares in China's listed commercial banks should be reduced, and social capital should be introduced. At the same time, the state should seek more control chain to strengthen the control over Chinese listed commercial banks.
\end{abstract}

\section{Keywords}

Listed Commercial Banks, Ownership Structure, Ownership Concentration, Check-and-Balance of Ownership, The Separation of the Two Powers, Market Value

\section{Introduction}

Along with the acceleration of China's financial reform, the rapid development of small and medium-sized commercial banks and the emergence of Internet 
finance, China's financial industry faces severe transformational crisis and challenges. The external Sino-US trade war has become increasingly fierce, which increases the risk of loan for import-export trade and manufacturing. Domestic Internet Finance has a strong impact on Chinese traditional banking industry, which has severely squeezed the business growth model of commercial banks with interest rate differentials, making the domestic financial industry increasingly competitive. Internet finance diverts savings deposits from commercial Banks, squeezes intermediate business of commercial Banks and impacts loan business of commercial Banks. Zou Wei et al. [1] believed that internet finance, such as P2P, has a large impact on small and medium-sized commercial banks, and has squeeze effect on liquidity creation. They also think, on the one hand, the internet finance weakens the banks' market power and profitability and reduces liquidity creation. On the other hand, the competitiveness of internet finance impacts the traditional business of banks in terms of threshold, cost and information. Chen Xiaoming et al. [2] found that the stability of commercial banks is significantly affected by the impact of internet finance.

As a commercial bank that dominates the financial industry and operates special business, it is an urgent problem for commercial banks to maintain their competitive advantages and improve their risk management capabilities and business performance. He Meiling and Hong Zheng [3] argued that sound and effective corporate governance is the most fundamental and key core competitiveness of banks, and ownership structure is the foundation of corporate governance. This paper believes that optimizing the shareholding structure plays an important role in enhancing market value. And this paper studies the market value of Chinese listed commercial banks from the perspectives of equity concentration, equity balance, and separation of rights.

\section{Theoretical Analysis and Research Hypothesis}

\subsection{Shareholding Ratio of Large Shareholders, Ownership Concentration and Market Value}

The influence of ownership concentration on corporate performance will be significantly different according to the external governance environment [4] [5]. China's financial system has not evolved step by step from economic development, but has been driven by the state. In fact, the management of Chinese listed commercial banks has the dual status of government officials and professional managers. And Chinese commercial banks cannot operate without their political tasks. Therefore, in the face of the growth opportunities of commercial banks, the management tends to be conservative and miss the opportunity for the growth of commercial banks. For example, compared with the United States, most of the listed commercial banks in China derive their operating income from deposits and loans, and the intermediary business operates. On the other hand, when management assumes politicians, it may be that some economic ac- 
tivity itself conflicts with the operation of commercial banks, but it is forced to carry out this activity. Similarly, Iannotta et al. [6] found that state-owned banks in Western European countries will be subject to a greater degree of government intervention and protection during election years, and their business risks will also increase. Bertay et al. [7] argued that lending by state banks in high income countries is even countercyclical. Therefore, this paper holds that if the proportion of the largest shareholder of China's listed commercial bank is higher, the market value of the listed commercial bank will be relatively low. This is the first hypothesis of this article.

H1: If the proportion of the largest shareholder of China's listed commercial bank is higher, the market value of the listed commercial bank will be relatively low.

On the question of the effects of ownership structure on performance both concentration indices and control-type dummies have significant effects on a vector of performance indicators [8]. Shleifer and Vishny [9] said that equity concentration can weaken the phenomenon of "hitchhiking" of minority shareholders to prevent management from making self-interest behavior that harms the interests of shareholders, and reduce the agency cost between shareholders and management. Claessens and Djankov et al. [10] hold this view, too. If the shareholder's equity changes frequently, it will have an impact on the normal operation of the company, especially the long-term development strategy of the company. Generally, due to the relatively good profitability of commercial banks and the large amount of bank equity financing in China, the transfer of equity of major shareholders is relatively rare. If the shares held by the five shareholders holding the most shares in the listed commercial banks are relatively large, it means that the commercial banks as a whole are relatively stable and the corresponding market value is also high. Therefore, this paper holds that if the sum value of the top five shareholding ratios of a listed commercial bank is large, the market value of the listed commercial bank will be higher. This is the second hypothesis of this article.

$\mathrm{H} 2$ : If the sum value of the top five shareholding ratios of a listed commercial bank is large, the market value of the listed commercial bank will be higher.

\subsection{Check-and-Balance of Ownership and Market Value}

Shleifer and Vishny [11] believed that major shareholders use their position of control to engage in the infringement of the interests of minority shareholders "tunneling" behavior, which resulted in conflicts of interest and increased agency costs between major shareholders and minority shareholders. Wang Xin and Han Baoshan [12] said that a moderately centralized ownership structure and checks and balances among several major shareholders are conducive to the improvement of corporate performance. Liu Haiyu and Sun Fuhua [13] found that there is lower significant positive correlation between controlling shareholder's shareholding ratio and enterprise performance when the controlling shareholder 
is a state-owned shareholder.

If a listed commercial bank has a higher shareholding ratio, the shareholder has the possibility to make a self-interest. If the largest shareholder of a listed commercial bank holds a higher proportion of shares, then there is the possibility that the shareholder will act in order to harm others. If the shareholding ratio of the largest shareholder of a listed commercial bank is not much different from the shareholding ratio of the second largest shareholder, the two can supervise each other. What's more, this relationship can help commercial banks to make more reasonable behaviors, for example, enhancing their position in the market, improving their market value. Therefore, this paper holds that if the value that the shareholding ratio of the largest shareholder divided by the shareholding ratio of the second largest shareholder is larger, the market value of the listed commercial bank will be lower. That is to say, the better balance among several major shareholders, the higher its market value. This is the third hypothesis of this article.

H3: If the result that the shareholding ratio of the largest shareholder divided by the shareholding ratio of the second largest shareholder is larger, the market value of the listed commercial bank will be lower.

\subsection{The Separation of the Two Powers and Market Value}

Studies on the influence of separation of two powers on enterprise value have drawn inconsistent conclusions. Some scholars think that separation of two powers is more likely to lead to hollowing out effect, while others think that separation of two powers is more likely to lead to support effect. Many studies found that the separation of two powers can lead to the actual controller tunneling the enterprise, and then lead to the reduction of enterprise value, such as Bae et al. [14], Liu Qigui and Gary [15], Wang Peng and Zhou Lian [16], Marchica and Mura [17]. However, Fama found that the separation of control and ownership helps maximize the market value of wealth [18]. And the latest study based on China's listed companies of Tian Lihui et al. [19] believed that separation of rights in the government-controlled enterprises can help prevent the occupation of funds, increase dividends, and reduce the related-party transactions, as well as reduce the social burdens and agency costs. Thus, in the firms with the government as the controlling shareholder, the separation of rights can reduce political intervention, deter the grabbing hand and enhance the marketization level of corporate operation.

Maintaining the stability of the actual controller is very important for the long-term operation of the company. The actual controller's control over the listed commercial banks usually shows a pyramid-type equity relationship. The longer the actual controller's control chain for the listed commercial banks, the higher the communication management cost of the actual controller's management of the listed commercial banks, and the worse the communication management effect. However, since most of the owners of listed commercial banks in 
China are state-owned and most of them do not have professional knowledge to operate the banks, then the higher equity separation of enterprises will result in greater value. Therefore, this paper holds that if the degree of separation between control and ownership of a listed commercial bank is very high, its market value will be relatively high. This is the fourth hypothesis.

H4: If the degree of separation between control and ownership of a listed commercial bank is very high, its market value will be relatively high.

\section{Research Design and Empirical Analysis}

\subsection{Selection of Samples}

Since 2002, China's commercial Banks have optimized their ownership structure by introducing strategic investment and IPO. The listed commercial banks increase the liquidity of their shares by introducing tradable shares, so their equity structure is further optimized compared with that of unlisted banks. The study on their ownership structure is also of certain reference significance to other commercial banks. By the end of 2018, only 28 commercial banks had gone public. Considering the availability of data and the richness of samples, we selected the cross-section data of 2018 to study the relationship between ownership structure and market value of commercial Banks.

The sample used in this article is from the listed commercial banks on the China Exchange as of 2018, which is showed in Table 1. The sample includes 28 commercial Banks listed on the Shanghai and Shenzhen Stock Exchanges as of the end of 2018. The study found that there are some listed commercial banks that do not have actual controllers, and this paper removed these banks in empirical process. The data sources are the East money and the annual reports of

Table 1. The samples of listed commercial Banks.

\begin{tabular}{|c|c|c|c|c|c|}
\hline Ticker & Name & Year of IPO & Ticker & Name & Year of IPO \\
\hline 000001 & Ping An Bank Co., Ltd. & 1991 & 601166 & Industrial Bank Co., Ltd. & 2007 \\
\hline 002142 & Bank of Ningbo Co., Ltd. & 2007 & 601169 & Bank of Beijing Co., Ltd. & 2007 \\
\hline 002807 & Jiangsu Jiangyin Rural Commercial Bank Co., Ltd. & 2016 & 601229 & Bank of Shanghai Co., Ltd. & 2016 \\
\hline 002839 & Jiangsu Zhangjiagang Rural Commercial Bank Co., Ltd. & 2017 & 601288 & Agricultural Bank of China Limited & 2010 \\
\hline 002936 & Bank of Zhengzhou Co., Ltd. & 2018 & 601328 & Bank of Communications Co., Ltd. & 2007 \\
\hline 600000 & Shanghai Pudong Development Bank Co., Ltd. & 1999 & 600015 & Hua Xia Bank Co., Ltd. & 2003 \\
\hline 600016 & China Minsheng Banking Corp., Ltd. & 2000 & 600036 & China Merchants Bank Co., Ltd. & 2002 \\
\hline 603323 & Jiangsu Suzhou Rural Commercial Bank Co., Ltd. & 2016 & 601577 & Bank of Changsha Co., Ltd. & 2018 \\
\hline 600908 & Wuxi Rural Commercial Bank Co., Ltd. & 2016 & 601818 & China Everbright Bank & 2010 \\
\hline 600919 & Bank of Jiangsu Co., Ltd. & 2016 & 601838 & Bank of Chengdu Co., Ltd. & 2018 \\
\hline 601009 & Bank of Nanjing Co., Ltd. & 2007 & 601988 & Bank of China Limited & 2006 \\
\hline 601128 & Jiangsu Changshu Rural Commercial Bank Co., Ltd. & 2016 & 601997 & Bank of Guiyang Co., Ltd. & 2016 \\
\hline 601398 & Industrial and Commercial Bank of China Limited & 2006 & 601998 & China Citic Bank Corporation Limited & 2007 \\
\hline
\end{tabular}

Source: East money and the annual reports of listed commercial banks. 
listed commercial banks.

\subsection{Variable Selection and Definition}

In this paper, the variables used are divided into three categories: explained variables, explanatory variables and control variables. The explanatory variable is a variable that describes the market value of commercial Banks. The explanatory variables of this paper are mainly used to represent the shareholding structure of listed commercial banks. This paper uses three variables, namely the ownership concentration ratio, the ratio of check-and-balance ownership and index of separation degree of ownership and control, to describe the ownership structure of listed commercial Banks. The control variables include the asset size and asset-liability ratio. All variables are described in detail below.

\subsubsection{Explained Variable}

Domestic and foreign scholars generally use an approximation of Tobin's Q [20] or the Market-to-Book Ratio (MBR) of a company's assets to evaluate the market performance of a company in the past. This paper uses MBR to measure the market performance of listed commercial banks for the reason that the information about MBR is easier to obtain.

\subsubsection{Explanatory Variables}

The explanatory variables of this paper are mainly used to represent the shareholding structure of listed commercial banks.

1) Ownership concentration ratio

Here, the proportion of shares held by the large shareholders in the listed commercial banks is used as a measure of the ownership concentration of the listed commercial banks. In order to better describe the ownership concentration of the listed commercial banks, the $S$ index was introduced during the research. The $S$ index is the sum of the shareholding ratios of the second to fifth largest shareholders of listed commercial banks. $R_{i}$ represents the proportion of the shares of the listed major commercial banks held by the i-large shareholder. The mathematical formula for the $S$ index is:

$$
S=\sum_{i=2}^{5} R_{i}
$$

2) The ratio of check-and-balance ownership

The $Z$ index is generally used to indicate the ability of company's checks and balances between the most shares and the second largest shareholder. When the $Z$ index is large, the shareholders holding the most shares in the listed commercial banks and the shareholders holding the second largest shares are not well constrained. The $Z$ index can better represent the equity balance.

$$
Z=\frac{R_{1}}{R_{2}}
$$

3) Index of separation degree of ownership and control

Here, the two-right separation index $(V C)$ is used to indicate the difference 
between the actual controller of the listed commercial bank and the holder the listed commercial bank. The right of the actual controller in a listed commercial bank to speak or influence the important matters is expressed by control ( $V$ ). The proportion of dividends that the actual controller can obtain from the listed commercial banks is expressed by ownership $(C)$. The actual controller of the listed commercial bank is the product of the ownership ratio of its control chain. If there is a consistent controller agreement, then this quantified value is the sum of the proportions of each concerted person. The quantitative calculation formula of the actual controller's ownership $(C)$ :

$$
C=X_{1} \times X_{2} \times \cdots \times X_{n}
$$

$V$ is the smallest holding ratio of the control chain in the listed commercial bank. As shown in Figure 1, the actual controller controls $N$ company through a single control chain. The value of $V$, which the actual controller's control over $N$ company, is equal to the minimum shareholding ratio in this chain. The quantitative calculation formula of actual controller's control right $(V)$ :

$$
V=\min \left(X_{1}, X_{2}, X_{3}, \cdots, X_{i}\right)
$$

$X_{i}$ is the controlling ratio that actual controller to company $i$. If the actual controller of the listed commercial bank controls more than one control chain of the listed commercial bank, then $V$ is the sum of the minimum holding ratios in each control chain. The index $V C$ is the ratio of the difference to $V$, while the difference equals to the difference between $V$ and $C$. The specific control chain is subject to the annual report of the listed commercial bank.

\subsubsection{Control Variables}

Listed commercial banks will encounter various problems in their operations. At different stages, listed commercial banks will face different problems. In some cases, listed commercial banks will choose an expansionary development strategy. In some cases, listed commercial banks will choose a tightening development strategy. No matter which strategy is involved, one factor always mentioned is cash flow. As a listed commercial bank, you must first have a certain asset size. Assets can provide protection during the expansion period and are equally important during the austerity period. Of course, listed commercial banks will be affected by many internal and external factors throughout their life cycle. The external factors of listed commercial banks may not be able to be changed through individual efforts, but to a certain extent, they can promote the development of listed commercial banks by influencing the internal factors of the enterprise. This paper selects some of the easily quantified influencing factors as control variables to carry out the next study.

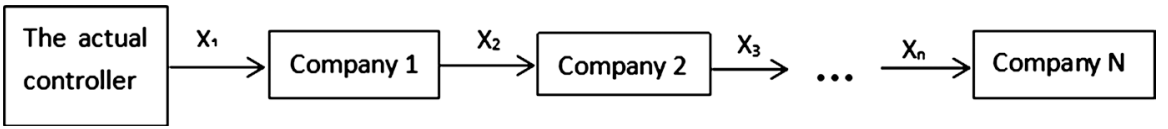

Figure 1. Control chain diagram. 


\section{1) Asset size}

Since commercial banks operate currency and they act as intermediaries between fund providers and demanders, assets are especially important for commercial banks. The size of an asset directly determines the scale of its operations. At the same time, the size of a commercial bank's assets determines its ability to conduct business and, to a certain extent, determines its share of the market. In addition, because commercial banks are in an important position in the financial system, their asset size also directly determines their ability to resist risks and the risk coefficient of operation. All in all, the size of a commercial bank's assets determines the market value to a certain extent.

2) Asset-liability ratio

Due to the commercial banks' important position in the financial system and the particularity of the operating currency, the control of risks is particularly important for commercial banks. In the management of modern commercial banks, assets and liabilities are not separately managed, but are linked, that is, asset-liability management. A reasonable capital structure, or the best asset-liability ratio, is very important for the operation of listed commercial banks. If the listed commercial banks are at an optimal asset-liability ratio, it can create higher value for shareholders and markets.

All the above variables are shown in Table 2.

\subsection{Research Analysis Method}

The general model established in this paper is as follows:

$$
M B R=\alpha+\beta_{1} C R+\beta_{2} S+\beta_{3} Z+\beta_{4} V C+\beta_{5} S I Z E+\beta_{6} D E T
$$

Table 2. The variable indicators.

\begin{tabular}{|c|c|c|}
\hline Variable name & indicator name & description \\
\hline $\begin{array}{l}\text { The shareholding ratio of } \\
\text { the largest shareholder }\end{array}$ & $C R$ & Shareholding ratio of the largest shareholder of a listed commercial bank. \\
\hline$S$ index & $S$ & $\begin{array}{l}\text { The sum of the shareholding ratio of the second to fifth largest shareholders of listed commercial } \\
\text { banks. }\end{array}$ \\
\hline$Z$ index & $Z$ & $\begin{array}{l}\text { The shareholding ratio of the largest shareholder of a listed commercial bank is divided by the } \\
\text { shareholding ratio of the second largest shareholder. }\end{array}$ \\
\hline Control & $V$ & The discourse power of the actual controller on the important matters in a listed commercial bank. \\
\hline Ownership & $C$ & $\begin{array}{l}\text { The actual controller can obtain the proportion of dividends from the listed commercial banks } \\
\text { under his control. }\end{array}$ \\
\hline $\begin{array}{l}\text { Index of separation degree } \\
\text { of ownership and control }\end{array}$ & $V C$ & $V C=($ control - ownership $) /$ Control. \\
\hline $\begin{array}{l}\text { Market value to book value } \\
\text { ratio of corporate assets }\end{array}$ & $M B R$ & $\begin{array}{l}M B R=\text { (the book value of the total liabilities }+ \text { the number of non-tradable shares } \times \text { the net assets } \\
\text { per share }+ \text { the number of tradable shares } \times \text { the average of the daily closing price of the tradable } \\
\text { shares in December of the year)/book value of total assets. }\end{array}$ \\
\hline Asset size & $S I Z E$ & $S I Z E=\operatorname{Ln}($ final assets at the end of the period). \\
\hline Asset-liability ratio & $D E T$ & Ratio of liabilities to assets. \\
\hline
\end{tabular}


$M B R$ represents the market value of the listed commercial banks. $C R$ represents the shareholding ratio of the largest shareholder of a listed commercial bank. $S$ represents the sum of the shareholding ratio of the second to fifth largest shareholders of listed commercial banks. This paper use $C R$ and $S$ to represent the ownership concentration ratio of a listed commercial bank. $Z$ equals the shareholding ratio of the largest shareholder of a listed commercial bank is divided by the shareholding ratio of the second largest shareholder, and $Z$ represents the ratio of check-and-balance ownership of a listed commercial bank. $V$ represents the discourse power of the actual controller on the important matters in a listed commercial bank. $C$ represents the actual controller can obtain the proportion of dividends from the listed commercial banks under his control. This paper use $V C$ to represent the separation degree of ownership and control. SIZE and DET represent the control variables. $\alpha$ represents the intercept of model. $\beta_{i}$ represents the correlation coefficient of the variables.

\subsection{Empirical Analysis}

\subsubsection{Descriptive Statistical Analysis}

Table 3 mainly shows the description of the sample of $C R, S$ index, $Z$ index, $V C$, $M B R, S I Z E$, and $D E T$.

As can be seen from Table 3, the $Z$ index has a maximum kurtosis of 13.2325 compared to the other six indicators. And the $Z$ index has the largest maximum difference from the mean. The standard deviation of some variables is less than their mean, such as $C R, S, Z, M B R, D E T$, while the standard deviation of $V C$ and $S I Z E$ is greater than their means. Relatively speaking, $S I Z E$ and $Z$ fluctuation are relatively large. In general, $C R, S, V C, M B R$, and $D E T$ are relatively stable.

\subsubsection{Correlation Analysis}

Table 4 shows the correlation $r$ values between $C R, Z, V C, M B R, S I Z E, D E T$, and $S$. Obviously, we can see that the $r$ index of $C R$ and $M B R$ is -0.61 , which means that there is a moderate negative correlation between the concentration of equity and the market value of commercial banks. That is to say, the shareholding ratio of the largest shareholder in a listed commercial banks higher, the lower of its market value. The $r$ value between $Z$ and $M B R$ is -0.42 , which means

Table 3. Description statistics.

\begin{tabular}{cccccccc}
\hline & Mean & Median & Maximum & Minimum value & Sum & Standard deviation & Kurtosis \\
\hline$C R$ & 0.2456 & 0.1857 & 0.6537 & 0.0436 & 5.8942 & 0.1791 & 3.2096 \\
$S$ & 0.2995 & 0.2941 & 0.6123 & 0.1243 & 7.1885 & 0.1317 & 2.5522 \\
$Z$ & 1.9222 & 1.4044 & 8.1112 & 1.0031 & 46.1331 & 1.5017 & 13.2325 \\
$V C$ & 0.2149 & 0.0630 & 0.7101 & 0.0000 & 1.9337 & 0.2696 & 2.1554 \\
$M B R$ & 0.9979 & 1.0004 & 1.0215 & 0.9746 & 23.9497 & 0.0125 & 2.1636 \\
$S I Z E$ & 10.9649 & 10.1711 & 12.3941 & 6.6574 & 98.6841 & 11.1954 & 3.7807 \\
$D E T$ & 0.9313 & 0.93 & 0.95 & 0.9 & 22.35 & 0.0123 & 3.0781 \\
\hline
\end{tabular}


that there is a weak negative correlation between the company's checks and balances and the market value. Similarly, if $Z$ of a listed commercial bank is higher, its market value is lower. The $r$ value between $V C$ and $M B R$ is 0.68 , which means that there is a moderate positive correlation between the separation degree of two rights and the market value of commercial banks. In the case of other factors unchanged, we hope that $V C$ will be higher, so that the market value of the commercial bank may be better.

\subsubsection{Regression Results and Analysis}

The fitting equation established from the regression results is:

$$
\begin{aligned}
\ln (M B R)= & 0.040181 \ln (C R)-0.066448 Z-12.84565 S^{6} \\
& +0.037506 V C-6.955719 \ln ^{2}(D E T)+0.208232
\end{aligned}
$$

This paper revises other indicators besides $Z$ and $V C$. The coefficient of $\ln$ $(C R)$ is 0.040181 , and the coefficient of $V C$ is 0.037506 . It is noteworthy that the effects of these two variables on $\ln (M B R)$ are positively correlated, that is, the effect on $M B R$ is also positively correlated. From Figure 2, we know $Z$ and $S$ are negatively correlated with $M B R$. Regression results showed that all variables passed the $5 \%$ significance test, and the R-squared was 0.9759 , and the overall fit of the model was higher. For the control variable $S I Z E$ and $D E T$, because of their highly linearly correlated, this paper removed $S I Z E$ as the corrected $S I Z E$ is

\begin{tabular}{|c|c|c|c|c|c|c|c|}
\hline & $C R$ & $Z$ & $V C$ & $M B R$ & SIZE & $D E T$ & $S$ \\
\hline$C R$ & 1 & 0.84 & -0.24 & -0.61 & 0.75 & -0.61 & -0.40 \\
\hline$Z$ & 0.84 & 1 & -0.14 & -0.42 & 0.40 & -0.27 & -0.79 \\
\hline$V C$ & -0.24 & -0.14 & 1 & 0.68 & -0.41 & 0.15 & 0.15 \\
\hline$M B R$ & -0.61 & -0.42 & 0.68 & 1 & -0.55 & 0.41 & 0.06 \\
\hline$S I Z E$ & 0.75 & 0.40 & -0.41 & -0.55 & 1 & -0.92 & -0.12 \\
\hline$D E T$ & -0.61 & -0.27 & 0.15 & 0.41 & -0.92 & 1 & 0.01 \\
\hline$S$ & -0.40 & -0.79 & 0.15 & 0.06 & -0.12 & 0.01 & 1 \\
\hline & \multicolumn{2}{|c|}{ Variable } & Coefficient & Std. Error & t-Statistic & \multicolumn{2}{|c|}{ Prob. } \\
\hline & \multicolumn{2}{|c|}{$\mathrm{C}$} & 0.208232 & 0.045711 & 4.555438 & \multicolumn{2}{|c|}{0.0198} \\
\hline & \multicolumn{2}{|c|}{$\operatorname{LOG}(C R)$} & 0.040181 & 0.010917 & 3.680672 & \multicolumn{2}{|c|}{0.0347} \\
\hline & \multicolumn{2}{|c|}{ Z } & -0.066448 & 0.012864 & -5.165541 & \multicolumn{2}{|c|}{0.0141} \\
\hline & \multicolumn{2}{|c|}{$S^{\wedge} 6$} & -12.84565 & 2.224398 & -5.774887 & \multirow{2}{*}{\multicolumn{2}{|c|}{0.0103}} \\
\hline & \multirow{2}{*}{\multicolumn{2}{|c|}{$\begin{array}{c}\text { VC } \\
\operatorname{LOG}(D E T)^{\wedge} 2\end{array}$}} & 0.037506 & 0.004948 & 7.580699 & & \\
\hline & & & -6.955719 & 1.747578 & -3.980206 & \multicolumn{2}{|c|}{$\begin{array}{l}0.0048 \\
0.0284\end{array}$} \\
\hline \multicolumn{3}{|c|}{ R-squared } & 0.975869 & \multicolumn{2}{|c|}{ Mean dependent var } & \multicolumn{2}{|c|}{-0.005392} \\
\hline & \multirow{2}{*}{\multicolumn{2}{|c|}{ Adjusted R-squared }} & 0.935650 & \multicolumn{2}{|c|}{ S.D. dependent var } & \multicolumn{2}{|c|}{0.013275} \\
\hline & & S.E. of regression & 0.003367 & \multicolumn{2}{|c|}{ Akaike info criterion } & \multicolumn{2}{|c|}{-8.314589} \\
\hline & \multicolumn{2}{|c|}{ Sum squared resid } & $3.40 \mathrm{E}-05$ & \multicolumn{2}{|c|}{ Schwarz criterion } & \multicolumn{2}{|c|}{-8.183106} \\
\hline & Log likeliho & & 43.41565 & Hannan-Qui & in criter. & -8.5 & \\
\hline & F-statistic & & 24.26417 & Durbin-Wats & on stat & 2.7 & \\
\hline & Prob(F-s tati & & 0.012452 & & & & \\
\hline
\end{tabular}

Table 4. Correlation statistics.

Figure 2. Regression results. 
insignificant. Then this paper establishes the above model by removing the control variable $S I Z E$.

\section{Conclusions}

This paper specifically divides the shareholding structure into three parts: equity concentration, equity balance, and separation of two powers. Then, this paper carries out empirical research on market value of Chinese listed commercial banks from these three angles. First, it is found that the high concentration of stock ownership of listed commercial banks will have a negative strongly impact on the enterprise value of listed commercial banks. Second, if the shareholding ratio of the largest shareholder of a listed commercial bank is less than the shareholding ratio of the second largest shareholder, it will have a positive impact on its market value. But this factor has a relatively low impact on its corporate value relative to the other two factors. If the largest shareholder of the listed commercial bank holds more shares, it will bring stability to the management of the listed commercial banks. At the same time, however, there also exists the possibility of damaging other shareholders. It may be that under the influence of this contradiction, the impact of this factor on the market value of listed commercial banks is relatively weak. Third, if the control of the actual controller of the listed commercial bank is highly separated from the ownership, it will have a positive impact on the market value. Generally speaking, the higher degree of separation shows that the actual controller controls the listed commercial banks through more control chains, which means the actual controller has less capitalized cost in a single listed commercial bank and increases the other investment opportunities for actual investors. Furthermore, it forms a bigger scale operation of the listed commercial banks.

In general, the proportion of shares held by Chinese listed commercial banks should be reduced. It is good for the Chinese listed commercial banks to introduce social capital, while the state should seek to control by seeking multiple control chains. This will not only control the key sectors of the national economic system, but also enhance the market operation capabilities of Chinese listed commercial banks. While enhancing the diversification of the shareholding structure of listed commercial banks, the Chinese government should establish and improve the supervision mechanism of the management. Allowing many small and medium shareholders to participate in corporate governance contributes to enhance the competitiveness of enterprises. Furthermore, these solutions can stabilize the long-term operation and increase the market value for listed commercial banks.

\section{Conflicts of Interest}

The author declares no conflicts of interest regarding the publication of this paper.

\section{References}

[1] Zou, W., Ling, J.H. and Zhao, X.J. (2018) Internet Finance, Bank Competition and 
Liquidity Creation. Economics and Management, 32, 44-50.

[2] Chen, X.M., Zhang, W. and Luo, Z.J. (2019) Impact of Internet Finance on the Stability of Commercial Banks. Academic Research, No. 1, 114-121.

[3] He, M.L. and Hong, Z. (2019) Private Capital Investment and Bank Performance Improvement-Based on Empirical Evidence of Urban Commercial Banks. Contemporary Finance and Economics, No. 7, 47-58.

[4] Reyna, J.M.S.M., Vázquez, R.D. and Valdés, A.L. (2012) Corporate Governance, Ownership Structure and Performance in Mexico. International Business Research, 5, 12-27. https://doi.org/10.5539/ibr.v5n11p12

[5] He, Y.L., Zhang, Y.W. and Mo, J.M. (2014) The Influence of Ownership Concentration on Corporate Performance under Different Regional Governance Environment. Financial Research, No. 12, 148-163.

[6] Iannotta, G., Nocera, G. and Sironi, A. (2013) The Impact of Government Ownership on Bank Risk. Journal of Financial Intermediation, 22, 152-176.

https://doi.org/10.1016/j.jfi.2012.11.002

[7] Bertay, A.C., Demirgüç-Kunt, A. and Huizinga, H. (2015) Bank Ownership and Credit over the Business Cycle: Is Lending by State Banks Less Procyclical? Journal of Banking and Finance, 50, 326-339. https://doi.org/10.1016/j.jbankfin.2014.03.012

[8] Leech, D. and Leahy, J. (1991) Ownership Structure, Control Type Classifications and the Performance of Large British Companies. The Economic Journal, 101, 1418-1437. https://doi.org/10.2307/2234893

[9] Shleifer, A. and Vishny, R.W. (1986) Large Shareholders and Corporate Control. Journal of Political Economy, 94, 461-488. https://doi.org/10.1086/261385

[10] Claessens, S., Djankov, S., Fan, J.P.H. and Lang, L.H.P. (2002) Disentangling the Incentive and Entrenchment Effects of Large Shareholdings. The Journal of Finance, 57, 2741-2771. https://doi.org/10.1111/1540-6261.00511

[11] Shleifer, A. and Vishny, R.W. (1997) A Survey of Corporate Governance. Journal of Finance, 52, 737-783. https://doi.org/10.1111/j.1540-6261.1997.tb04820.x

[12] Wang, X. and Han, B.S. (2018) Research on Governance Effect of Ownership Structure in Mixed Ownership Enterprises. Reform of Economic System, No. 6, 125-131.

[13] Liu, H.Y. and Sun, F.H. (2018) The Influence of State Ownership and Equity Checks and Balances on the Performance of Mixed Ownership Enterprises. Journal of $\mathrm{Wu}$ han University of Technology (Information and Management Engineering Edition), 40, 466-470.

[14] Bae, K.-H., Baek, J.-S., Kang, J.-K. and Liu, W.-L. (2012) Do Controlling Shareholders' Expropriation Incentives Imply a Link between Corporate Governance and Firm Value? Theory and Evidence. Journal of Financial Economics, 105, 412-435. https://doi.org/10.1016/j.jfineco.2012.02.007

[15] Liu, Q.G. and Tian, G. (2012) Controlling Shareholder, Expropriations and Firm's Leverage Decision: Evidence from Chinese Non-Tradable Share Reform. Journal of Corporate Finance, 18, 782-803. https://doi.org/10.1016/j.jcorpfin.2012.06.002

[16] Wang, P. and Zhou, L. (2006) Control Right, Ownership and Corporate Performance of Controlling Shareholders: Evidence Based on Listed Companies in China. Financial Research, No. 2, 88-98.

[17] Marchica, M.T. and Mura, R. (2005) Direct and Ultimate Ownership Structures in the UK: An Intertemporal Perspective over the Last Decade. Corporate Governance. An International Review, 13, 26-45. 
https://doi.org/10.1111/j.1467-8683.2005.00401.x

[18] Fama, E.F. and Jensen, M.C. (1983) Separation of Ownership and Control. The Journal of Law and Economics, 26, 301-325. https://doi.org/10.1086/467037

[19] Tian, L.H., Ye, Y. and Zhang, W. (2016) Separation of Two Powers and Long-Term Return of Listed Companies: Profit Expropriation or Power Simplification. World Economy, 39, 49-72.

[20] Drakos, A.A. and Bekiris, F.V. (2010) Corporate Performance, Managerial Ownership and Endogeneity: A Simultaneous Equations Analysis for the Athens Stock Exchange. Research in International Business and Finance, 24, 24-38.

https://doi.org/10.1016/j.ribaf.2009.01.002 